\title{
A morphological characterization of Borrelia anserina
}

\author{
Kari Hovind-Hougen $\dagger$
}

National Veterinary Laboratory, Copenhagen, Denmark

\begin{abstract}
The morphology and ultrastructure of two strains of Borrelia anserina were investigated by electron microscopy of negatively stained and ultrathin sectioned cells. One was a cultivable strain originally isolated in the USA and the other was originally isolated in Nigeria and maintained in chickens. The cells were regularly helical, 9-21 $\mu \mathrm{m}$ long and 0.22-0.26 $\mu \mathrm{m}$ wide with a helix wavelength of about $1.7 \mu \mathrm{m}$. The cells were surrounded by a surface layer and appeared to divide by binary fission. The structure of the cells from each of the two strains was identical except that those of the USA strain possessed seven flagella inserted at each end and those from the Nigerian strain had eight.
\end{abstract}

Keywords: Borrelia anserina, morphology, ultrastructure, spirochaetes

\section{INTRODUCTION}

Borrelia species are known to be the causative agents of several human and animal diseases, for example relapsing fever, but relatively few studies were carried out on members of the genus until 1982 when Borrelia burgdorferi was found to be the causative agent of Lyme disease (Burgdorfer et al., 1982).

The study of Borrelia species has been hampered by the fact that only a few of them can be cultivated in vitro (Kelly, 1984). The type species, Borrelia anserina, has for example traditionally been maintained in embryonated chicken eggs or by serial passage in young domestic chickens. In 1986, however, it was found that it could be cultivated in Barbour-Stoenner-Kelly (BSK) medium (Anderson et al., 1986; Barbour et al., 1986) and thus made more easily available for further investigations.

Several reports have recently described serological and immunological differences between various isolates of $B$. anserina (Felsenfeld, 1971; DaMassa \& Adler, 1979; Soni \& Joshi, 1980). The aim of the present work was to determine whether such differences were reflected in the morphology and ultrastructure of the organisms. Consequently, it was decided to investigate two isolates of $B$. anserina which had not previously been studied in detail. For this purpose, a cultivable strain and a strain passaged in chickens were chosen. Finally, the ultrastructure of $B$. anserina was compared with previously published data on the morphology of several other Borrelia species, including B. burgdorferi.

† Deceased 1993. Correspondence to: Dr P. C. Hougen, Jomfrubakken 19, DK-3500 Vaerlose.

\section{METHODS}

A subculture of $B$. anserina strain Es ATCC 49835 originally isolated by DaMassa \& Adler (1979) was obtained from Professor R. C. Johnson, University of Minnesota, Minneapolis, USA. The strain was maintained by culture in BSK medium (Barbour et al., 1986) at $32{ }^{\circ} \mathrm{C}$.

Blood from chickens infected with $B$. anserina in the northern region of Nigeria between 1966 and 1969 (Wouda et al., 1975; Leeflang \& Ilemobade, 1977) was obtained from Dr F. Jongejan, University of Utrecht, The Netherlands. The blood had been stored in liquid nitrogen for over 20 years (F. Jongejan, personal communication). Four chickens, about 6-8 weeks old, were inoculated intramuscularly with approximately $0.02 \mathrm{ml}$ of this blood. Blood samples from the chickens were examined daily by dark-field microscopy and the chickens were bled on day 4 , at which time there were too many organisms to count in each field at $\times 400$ magnification. The blood was left to clot at $+4{ }^{\circ} \mathrm{C}$ overnight and the serum containing the spirochaetes was pipetted off.

Procedure for negative staining. One- to two-week-old cultures and sera from infected chickens were centrifuged at $9000 \mathrm{~g}$ for $20 \mathrm{~min}$. The resulting pellets were resuspended to a suitable density in SMC $(0.03 \%, \mathrm{w} / \mathrm{v}$, sucrose in redistilled water to which was added $0.01 \mathrm{M} \mathrm{MgCl}_{2}$ and $0.01 \mathrm{M} \mathrm{CaCl}_{2}$ ). Some cells were treated on the grids with $1 \%(\mathrm{w} / \mathrm{v})$ sodium deoxycholate in water for 15 or $60 \mathrm{~s}$. Negatively stained samples were prepared by the multiple drop technique (Hovind-Hougen $\&$ Birch-Andersen, 1971) from the suspension or directly from the sera. Ammonium molybdate $(1 \%, \mathrm{w} / \mathrm{v})$ in redistilled water brought to $\mathrm{pH} 7$ with $\mathrm{NH}_{4} \mathrm{OH}$ was used for negative staining.

Procedure for ultrathin sectioning of cells from cultures. Cultures were centrifuged at $9000 \mathrm{~g}$ for $20 \mathrm{~min}$. Cell pellets were prefixed in $1.5 \%(\mathrm{v} / \mathrm{v})$ glutaraldehyde in $0.1 \mathrm{M}$ cacodylate buffer, $\mathrm{pH} 7 \cdot 2$. After fixation and centrifugation the cells were gently mixed with melted $1.5 \%(\mathrm{w} / \mathrm{v})$ Noble Agar (Difco) at $45^{\circ} \mathrm{C}$ in the same buffer and small blocks with visible clusters of 
Table 1. Comparison of morphological characters of $B$. anserina strains

\begin{tabular}{|lccccccc|}
\hline Strain & Length $(\boldsymbol{\mu m})$ & $\begin{array}{c}\text { Wavelength } \\
(\boldsymbol{\mu m})^{*}\end{array}$ & $\begin{array}{c}\text { Diameter } \\
(\boldsymbol{\mu m})^{*}\end{array}$ & $\begin{array}{c}\text { Ends } \dagger \\
\text { layer } \ddagger\end{array}$ & $\begin{array}{c}\text { Surface } \\
\text { flagella }\end{array}$ & $\begin{array}{c}\text { No. of } \\
\text { flagella }\end{array}$ \\
\hline Es-m & $8.9-20.1(13.9)$ & 1.75 & 0.22 & $\mathrm{P}$ & $\mathrm{T}$ & 7 & + \\
Ni-NL & $9.9-21.2(14.5)$ & 1.71 & 0.26 & $\mathrm{P}$ & $\mathrm{T}$ & 8 & + \\
\hline
\end{tabular}

* Mean of 80 estimations.

† $\mathrm{P}$, Pointed.

$\ddagger \mathrm{T}$, Triple layered.

cells were fixed overnight in 3\% glutaraldehyde, before postfixation in $1 \%(\mathrm{w} / \mathrm{v}) \mathrm{OsO}_{4}$, followed by impregnation in $2 \%(\mathrm{w} / \mathrm{v})$ aqueous uranyl acetate. Finally, the blocks were dehydrated in alcohol and propylene oxide prior to embedding in Vestopal W.

\section{Procedure for ultrathin sectioning of cells from infected blood. Serum was centrifuged at $9000 \mathrm{~g}$ for $20 \mathrm{~min}$ and most of it was removed, so that only about $0.2 \mathrm{ml}$ was left in the tube. One to $1.5 \mathrm{ml} 6 \%$ glutaraldehyde was added and the serum was left to solidify at room temperature. Clumps of Borrelia embedded in the coagulated serum were carefully dissected out and blocks with cells were trimmed to about $1 \mathrm{~mm}^{3}$. These blocks were fixed overnight in $1 \% \mathrm{OsO}_{4}$, treated with $2 \%$ uranyl acetate and dehydrated as described above.}

Electron microscopy. Ultrathin sections were prepared on an LKB ultratome and stained with magnesium uranyl acetate (Frasca \& Parks, 1965) and lead citrate (Reynolds, 1963) before examination in a Philips EM 200 electron microscope at primary magnifications of $\times 1500, \times 3000$ or $\times 10000$, or a Zeiss EM 109 electron microscope at primary magnifications of $\times 3000$ and $\times 20000$. Negatives were obtained on $35 \mathrm{~mm}$ Kodak Fine Grain Release Positive Film, type 5302, or $60 \mathrm{~mm}$ Kodak Plus X Pan Film, respectively, and prints were photographically enlarged to final magnifications of $\times 15000, \times 30000$ and $\times 100000$.

Approximately 250 micrographs were studied.

\section{RESULTS}

Cells of both strains of $B$. anserina were found to be regularly waved spirochaetes, 8.9-21.2 $\mu \mathrm{m}$ long and with a wavelength of about $1 \cdot 7 \mu \mathrm{m}$ (Table 1, Fig. 1a). The cells had tapered ends. The full width of $0.22-0.26 \mu \mathrm{m}$ was reached after 1-1.5 wavelengths from the ends. At high magnification, the cells from infected chicken blood were seen to possess eight flagella inserted at each end (Fig. 1b) whereas the cultivated cells possessed seven flagella inserted at each end (Fig. 1c). The cells appeared to be surrounded by a surface layer - here named the S-layer (Fig. 1c). Some micrographs showed, at the tip of the cells, a substructure of fine striations transverse to the cell (not shown). The cells appeared to divide by binary fission. Occasionally, dividing cells were seen in which the truncated ends of the two daughter cells were separated by their individual cytoplasmic membranes but still connected by the mutual outer membrane and S-layer (not shown). In these cells the insertion points of new flagella were present on either side of the division site. These observations are similar to those made on other spirochaetes.

Some cells were accidently damaged during preparation for electron microscopy. From these cells, and those treated with $1 \%$ sodium deoxycholate, the flagella were released from their insertions on the cytoplasmic bodies of the cells. The flagellar filament was seen to be sheathed (Fig. 1d), with an overall diameter of $19 \mathrm{~nm}$ and a core of $14 \mathrm{~nm}$ diameter. Thin, rather straight fibrils with a diameter of $4 \mathrm{~nm}$ were observed surrounding remnants of the cells treated with sodium deoxycholate (Fig. 1e). The basal complex of the flagellum was not completely freed from the cytoplasmic body of the cells after treatment with deoxycholate but was similar in structure to that seen previously (Hovind-Hougen, 1974; Soni \& Joshi, 1980), i.e. each complex consisted of two narrow discs connected to a hook by a narrow neck (Fig. 1f).

Cross-sectioned cells showed the flagella between the outer membrane and the cytoplasmic membrane (Figs $1 \mathrm{~g}, \mathrm{~h}$ ). The flagella from each end overlapped in two separate bundles and did not appear to be interdigitated (Fig. 1g). The cytoplasm of the cells was densely packed with ribosomes and some mesosome-like structures were occasionally present.

Cytoplasmic tubules of the type found in treponemal cells (Hovind-Hougen, 1976) were never observed in Borrelia cells during the present work.

\section{DISCUSSION}

The ultrastructure of the cells of the two strains examined in this study differed only in the number of flagella inserted at each end of the cells. The differences observed in wavelengths and widths of the organisms were considered to be of no significance. Differences in the number of flagella have previously been found for cells of $B$. burgdorferi isolates obtained from human patients. The cells isolated from patients in the USA had seven flagella inserted at each end whereas those isolated from Swedish patients had eight, and showed some serological differences in reaction when tested with monoclonal 

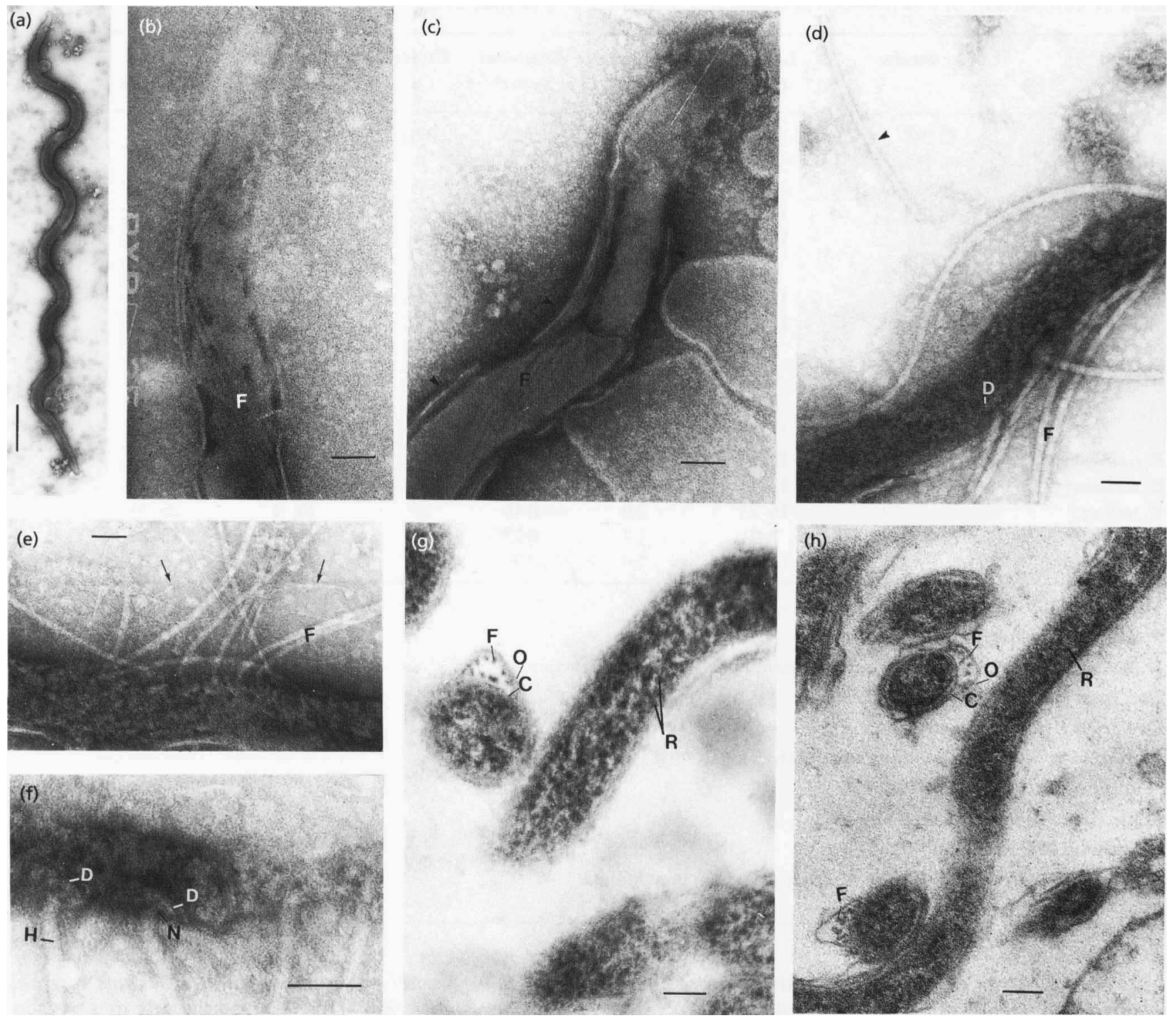

Fig. 1. Electron micrographs of $B$. anserina. (a)-( $f$ ) Cells negatively stained with $1 \%$ ammonium molybdate. (a) Regularly waved cell of a cultivable strain. (b) End of a cell of a strain isolated from chicken blood. The organism has eight flagella inserted at the end of the cell. The flagella are best counted in the region marked with the letter F. (c) End of a cell of a strain cultivated in BSK medium. The organism has seven flagella inserted at the end of the cell. The flagella are best counted in the region marked with the letter F. Note the triple layered borderline of the cell envelope (arrows). (d), (e), (f) Parts of cells of a strain cultivated in BSK medium and treated on the specimen grids with $1 \%$ sodium deoxycholate for $1 \mathrm{~min}$. $(\mathrm{d}, \mathrm{f})$ or $15 \mathrm{~s}(\mathrm{e})$. Some of the flagella (F) are still attached to the cellular debris. The basal complexes on some of the flagella can be seen to consist of two discs (D) connected to a hook (H) by a narrow neck (N). Part of an unsheathed flagellar shaft is present in (d) (arrowhead) and thin, rather straight fibrils are seen between the flagella in (e) (arrows). (g), (h) Ultrathin sectioned cells of cultivable $(\mathrm{g})$ and the non-cultivated $(\mathrm{h})$ strains of $B$. anserina. The flagella (F) are situated between the outer membrane (O) and the cytoplasmic membrane (C) of the cells. Note that the two bundles of flagella in the cross-sectioned cells do not interdigitate. The cytoplasm of the cells is densely packed with ribosomes (R). Bars: (a), $5 \mu \mathrm{m}$; (b)-(h), $100 \mathrm{~nm}$.

antibodies (Hovind-Hougen et al., 1986). Other spirochaetes, such as the cultivable treponemes, which show differences in numbers of flagella also show serological and antigenic differences to the extent that they are assigned to different species (Fiehn, 1989).
Distinct serological and immunological properties of different isolates of $B$. anserina are shown by lack of crossprotection against cells of heterologous isolates, and by the inability of sera from infected chickens to immobilize borrelia from heterologous isolates (DaMassa \& Adler, 
Table 2. Comparison of morphological characters of some Borrella species

\begin{tabular}{|c|c|c|c|c|c|c|c|c|}
\hline Species & Strain & $\begin{array}{c}\text { Length } \\
\text { ( } \mu \mathrm{m})\end{array}$ & $\begin{array}{l}\text { Wavelength } \\
(\mu \mathrm{m})^{*}\end{array}$ & $\begin{array}{c}\text { Diameter } \\
(\mu \mathrm{m})^{*}\end{array}$ & Ends† & Surface layer $\ddagger$ & $\begin{array}{l}\text { No. of } \\
\text { flagella }\end{array}$ & $\begin{array}{l}\text { Sheathed } \\
\text { flagella }\end{array}$ \\
\hline \multirow{5}{*}{$\begin{array}{l}\text { B. burgdorferi } \\
\text { (isolated from } \\
\text { Ixodes dammini) }\end{array}$} & G 74S & $8-15$ & $2 \cdot 3$ & 0.27 & $\mathrm{P} / \mathrm{B}$ & $\mathrm{D}, \mathrm{A} / \mathrm{S}, \mathrm{R}$ & $8 / 11$ & + \\
\hline & G 1525 & $8-13$ & $2 \cdot 6$ & $0 \cdot 26$ & $\mathrm{~B}$ & $\mathrm{~S}, \mathrm{R}$ & 8 & + \\
\hline & F 15 & $7-18$ & $2 \cdot 8$ & $0 \cdot 38$ & $\mathbf{P}$ & $\mathrm{D}, \mathrm{A}$ & 8 & $?$ \\
\hline & G 25\| & $10-24$ & $2 \cdot 2$ & $0 \cdot 24$ & $\mathbf{P}$ & $\mathrm{D}, \mathrm{A}$ & 11 & + \\
\hline & B $31 \|$ & $13-16$ & $2 \cdot 6$ & $0 \cdot 22$ & $P$ & $\mathrm{~S}, \mathrm{~A}$ & $7 / 11$ & + \\
\hline \multirow{7}{*}{$\begin{array}{l}\text { B. burgdorferi } \\
\text { (isolated from } \\
\text { human patients) }\end{array}$} & ECM-2\$ & $9-23$ & $2 \cdot 4$ & $0 \cdot 26$ & $\mathrm{P}$ & $\mathrm{D}, \mathrm{A}$ & 8 & + \\
\hline & ECMA-6\$ & $12-21$ & $2 \cdot 5$ & 0.25 & $\mathrm{P}$ & $\mathrm{D}, \mathrm{A}$ & 8 & + \\
\hline & DK-19 & $11-17$ & $2 \cdot 5$ & $0 \cdot 25$ & $\mathrm{P}$ & $\mathrm{S}, \mathrm{A}$ & 8 & $?$ \\
\hline & ACA-1S & $8-21$ & $2 \cdot 5$ & 0.29 & $\mathrm{P}$ & $\mathrm{D}, \mathrm{A}$ & 8 & + \\
\hline & 2725 & $8-16$ & $3 \cdot 0$ & $0 \cdot 25$ & $\mathrm{P}$ & $\mathrm{S}, \mathrm{A}$ & 7 & + \\
\hline & $297 \$$ & $8-15$ & $3 \cdot 3$ & $0 \cdot 25$ & $\mathrm{P}$ & $S, A$ & 7 & - \\
\hline & $20 * *$ & $12-20$ & $2 \cdot 2$ & $0 \cdot 28$ & $P$ & S, A & 8 & + \\
\hline \multicolumn{2}{|l|}{ B. recurrentis $\dagger \dagger$} & $12-17$ & $1 \cdot 8$ & 0.50 & SP & $\mathrm{D}, \mathrm{A}$ & $15-20$ & - \\
\hline \multicolumn{2}{|l|}{ B. merionesit† } & $12-17$ & $1 \cdot 7$ & $0 \cdot 40$ & SP & $\mathrm{D}, \mathrm{A}$ & $15-20$ & - \\
\hline \multicolumn{2}{|l|}{ B. persica $\ddagger \ddagger$} & $16-23$ & $2 \cdot 0$ & $0 \cdot 45$ & SP & $\mathrm{D}, \mathrm{R}$ & $25-30$ & - \\
\hline \multicolumn{2}{|l|}{ B. microtis $\int$} & $7-21$ & $1 \cdot 7$ & $0 \cdot 22$ & SP & $\mathrm{D}, \mathrm{A}$ & $15-20$ & - \\
\hline \multicolumn{2}{|l|}{ B. baltazardi $\ddagger \ddagger$} & $14-20$ & $2 \cdot 0$ & 0.35 & SP & $\mathrm{D}, \mathrm{A}$ & 25 & - \\
\hline
\end{tabular}

* Mean of 50-100 estimations.

$\uparrow \mathrm{P}$, pointed; $\mathrm{B}$, blunt; $\mathrm{SP}$, sharply pointed.

$\ddagger D$, double contour; $S$, single contour; $A$, amorphous; $R$, regular structure.

$\int$ Data from Hovind-Hougen et al. (1986).

|| Data from Hovind-Hougen (1984).

g K. Hansen \& K. Hovind-Hougen, unpublished.

** Data from Karlsson et al. (1990).

t† Data from Hovind-Hougen (1974).

$\ddagger \ddagger$ Data from Karimi et al. (1979).

\\K. Hovind-Hougen, Y. Karimi \& A. Birch-Andersen, unpublished.

1979; Soni \& Joshi, 1980). The ultrastructure of these isolates has apparently not been examined. Conversely, no attempt was made to investigate the immunological and serological properties of the isolates studied in the present work.

Cells of $B$. anserina differ from those of $B$. burgdorferi by having a shorter wavelength (Tables 1 and 2).

The outer membrane of $B$. anserina is covered by a surface layer with a substructure of fine striations. Such striations are also seen on cells from European isolates of $B$. burgdorferi whereas no substructure and no S-layer are seen on cells from American isolates (Hovind-Hougen et al., 1986). The morphology of cells of $B$. anserina also differs from that of previously examined cells of $B$. recurrentis and some borrelia strains isolated in Iran and Africa (HovindHougen, 1974; Karimi et al., 1979). The B. anserina cells are thinner and less pointed in shape and contain fewer flagella, which are sheathed in contrast to those of the $B$. recurrentis group which possess unsheathed flagellar shafts (Table 2).

In recent studies on the antigenic relatedness of $B$. anserina and $B$. burgdorferi only one strain of $B$. anserina was used (Walker et al., 1989). This was also the case in a study on attenuation of $B$. anserina by serial passage in liquid medium (Levine et al., 1990). Further comparative studies on the morphology, metabolism, and antigenic and genetic characters of different $B$. anserina strains are needed before the necessary criteria for a full description of the type species of the genus Borrelia can be given.

\section{ACKNOWLEDGEMENTS}

I am indebted to Dr R. M. Dwars, University of Utrecht, The Netherlands, for establishing my contact with Dr F. Jongejan, Institute of Infectious Diseases, Faculty of Veterinary Medicine, also at the University of Utrecht. Dr Jongejan kindly provided me with the Nigerian strain of B. anserina. I am also indebted to Professor R. C. Johnson, Department of Microbiology, University of Minnesota, Minneapolis, USA, for providing me with the cultivable strain of $B$. anserina. In addition, I am grateful to Dr B. Brest Nielsen for helping me with the infection of the chickens, and to Dr A. Birch-Andersen for his advice and help with the preparation of the manuscript. Finally, I wish to thank L. Jakobsen for sectioning and electron microscopy, E. Müller 
for the photographic work and K. Moeller for secretarial assistance.

\section{REFERENCES}

Anderson, J. F., Johnson, R. C., Magnarelli, L. A. \& Hyde, F. W. (1986). Involvement of birds in the epidemiology of the Lyme Disease agent Borrelia burgdorferi. Infect Immun 51, 394-396.

Barbour, A. G., Hayes, S. F., Heiland, R. A., Schrumpf, M. E. \& Tessier, S. L. (1986). A Borrelia-specific monoclonal antibody binds to a flagellar epitope. Infect Immun 52, 549-554.

Burgdorfer, W., Barbour, A. G., Hayes, S. F., Benach, J. L., Grunwaldt, E. \& Davis, J. P. (1982). Lyme disease, a tick-borne spirochetosis? Science 6, 1317-1319.

DaMassa, A. J. \& Adler, H. E. (1979). Avian spirochetosis: natural transmission by Argas (Persicargas) sanchezi (Ixodoidea: Argasidae) and existence of different serologic and immunologic types of Borrelia anserina in the United States. Am J Vet Res 40, 154-157.

Felsenfeld, 0. (1971). In Borrelia. Strains, Vectors, Human and Animal Borreliosis, pp. 139-142. St Louis, MI, USA: Warren H. Green.

Fiehn, N. E. (1989). Small-sized oral spirochetes and periodontal disease. APMIS, Suppl 7, no. 97, 4-31.

Frasca, J. M. \& Parks, V. R. (1965). A routine technique for doublestaining ultrathin sections using uranyl and lead salts. J Cell Biol 25, 157-161.

Hovind-Hougen, K. (1974). Electron microscopy of Borrelia merionesi and Borrelia recurrentis. Acta Pathol Microbiol Scand Sect B Microbiol 82, 799-809.

Hovind-Hougen, K. (1976). Determinations by means of electron microscopy of morphological criteria of value for classification of some spirochetes, in particular treponemes. Acta Pathol Microbiol Scand Sect B Microbiol, Suppl no. 255, 1-41.

Hovind-Hougen, K. (1984). Ultrastructure of spirochetes isolated from Ixodes ricinus and Ixodes dammini. Yale J Biol Med 57, 543-548.

Hovind-Hougen, K. \& Birch-Andersen, A. (1971). Electron mi- croscopy of endoflagella and microtubules in Treponema Reiter. Acta Patbol Microbiol Scand Sect B Microbiol 79, 37-50.

Hovind-Hougen, K., Åsbrink, E., Stiernstedt, G., Steere, A. C. \& Hovmark, A. (1986). Ultrastructural differences among spirochetes isolated from patients with Lyme disease and related disorders, and from Ixodes ricinus. Zentralbl Bakteriol Mikrobiol Hyg $\operatorname{Ser} A$ 263, 103-111.

Karimi, Y., Hovind-Hougen, K., Birch-Andersen, A. \& Asmar, M. (1979). Borrelia persica and B. baltazardi sp. nov.: Experimental pathogenicity for some animals and comparison of the ultrastructure. Ann Microbiol (Paris) 130B, 157-168.

Karlsson, M., Hovind-Hougen, K., Svenungsson, B. \& Stiernstedt, G. (1990). Cultivation and characterization of spirochetes from cerebrospinal fluid of patients with Lyme Borreliosis. J Clin Microbiol 28, 473-479.

Kelly, R. T. (1984). Borrelia. In Bergey's Manual of Systematic Bacteriology, vol. 1, pp. 59-62. Edited by N. R. Krieg \& J. G. Holt. Baltimore: Williams \& Wilkins.

Leeflang, P. \& llemobade, A. A. (1977). Tick-borne diseases of domestic animals in Northern Nigeria. II. Research summary, 1966 to 1976. Trop Anim Health Prod 9, 211-218.

Levine, J. F., Dykstra, M. J., Nicholson, W. L., Walker, R. L. \& Massey, G. (1990). Attenuation of Borrelia anserina by serial passage in liquid medium. Res $V$ et Sci 48, 64-69.

Reynolds, E. S. (1963). The use of lead citrate at a high $\mathrm{pH}$ as an electron opaque stain in electron microscopy. $J$ Cell Biol 17, 208-212.

Soni, J. L. \& Joshi, A. G. (1980). A note on strain variation in Akola and Jabalpur strains of Borrelia anserina. Zentralbl Veterinaermed Reibe B 27, 70-72.

Walker, R. L., Greene, R. T., Nicholson, W. L. \& Levine, J. F. (1989). Shared flagellar epitopes of Borrelia burgdorferi and Borrelia anserina. Vet Microbiol 19, 361-371.

Wouda, W., Schillhorn van Veen, T. W. \& Barnes, H. J. (1975). Borrelia anserina in chickens previously exposed for Borrelia theileri. Avian Dis 19, 209-210.

Received 6 July 1994; accepted 24 August 1994 